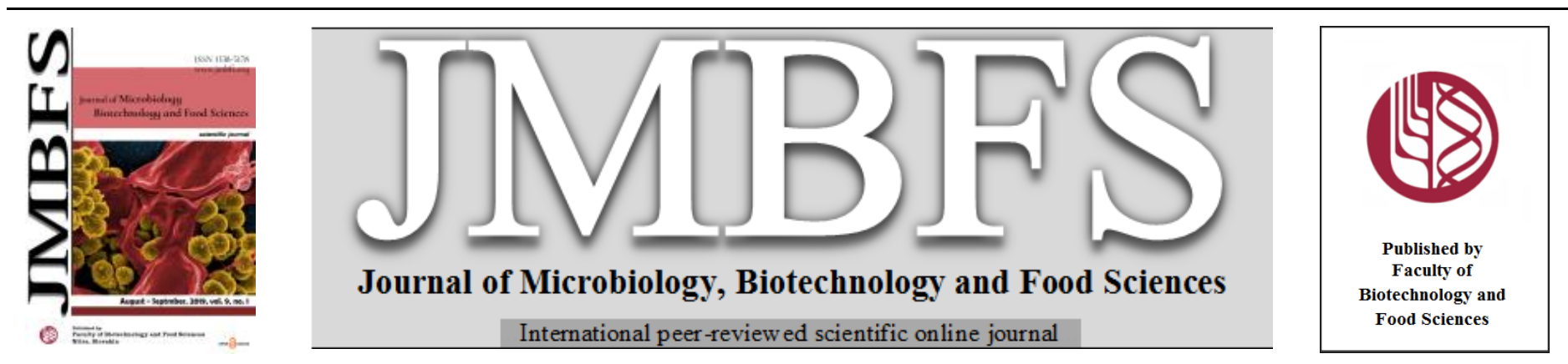

\title{
ALLELOPATHIC POTENTIAL OF SUGAR SORGHUM (SORGHUM BICOLOR (L.) MOENCH) SEEDS
}

\author{
Larysa Storozhyk ${ }^{1}$, Valery Mykolayko ${ }^{2}$, Iryna Mykolayko ${ }^{2}$ \\ Address(es): Larysa Storozhyk, Doctor of Agricultural Sciences \\ ${ }^{1}$ Institute of Bioenergy Crops and Sugar Beet National Academy of Agricultural Sciences of Ukraine, Department of Genetics and Biotechnology, \\ 25 Klinichna St., 03110 Kyiv, Ukraine +380501574328 . \\ ${ }^{2}$ Pavlo Tychyna Uman State Pedagogical University, Ministry of Education and Science of Ukraine \\ 2 Sadova St., 20300 Uman, Cherkasy region, Ukraine.
}

*Corresponding author: larisastorozhyk1501@gmail.com

doi: 10.15414/jmbfs.2019.9.1.93-98

\section{ARTICLE INFO}

Received 13.9. 2018

Revised 19.3. 2019

Accepted 19.3. 2019

Published 1. 8. 2019

Regular article

OPEN OACCESS

\section{ABSTRACT}

Allelopathic effect of water extracts of crushed sweet sorghum seeds of hybrids 'Medovyi' and 'Dovista' and variety 'Sylosne 42' and their effect on sugar beet (Beta vulgaris L.) seeds germination of hybrid 'Ukrainian MS 97' is presented. Water extracts of various concentrations (from 5 to $50 \%$ ) were prepared. The results were compared with the control treatment (distilled water). To estimate the growth rate of plants, the number of buds and leaves, plant height and the general condition of plants were examined. In regard to the chemical interaction of crops in mixed cropping, it was found that water extracts from sorghum seeds have a significant a mount of allelopathically active substances revealing both phytotoxic and stimulating effects on the germination and germination vigour of sugar beet seeds. The water extracts of 'Medovyi' seeds showed the lowest allelopathic effect compared to other cultivars under study. Water extract of 'Sylosne 42' appeared relatively tolerant to germination of sugar beet seeds.

The extract of 'Medovyi' seeds was filtered and added into the agar medium on which the clones of Beta vulgaris L. were planted. Allelopathically active substances did not affect sugar beet plants on the $7^{\text {th }}$ day after planting. A decrease in the number of buds, leaves and plant height was recorded on the $14^{\text {th }}$ day. On the $21^{\text {st }}$ day, sugar beet plants looked suppressed and eventually died off. Understanding of physical and biochemical mechanisms of plants interaction allows selecting physiologically compatible plants for high-productive phytocoenoses.

Keywords: germination vigour, inhibiting effect, in vitro, seed extracts

\section{INTRODUCTION}

Scientific and technological progress builds on the created by man material resources and technologies which often do not consider natural phenomena. This resulted in a number of such negative consequences as an ecological crisis, the lack of raw resources, etc. The most serious changes in the environment are connected with agro-industrial production, and they are clearly seen in the disorder of natural, biological and geological cycles of substances and energy, the reduction of biological diversity, the change of structure and major properties of natural landscapes, pollution and violation of the reproduction processes of renewable resources. Therefore, at the current state of the economy, allelopathy, which is a rather new tendency in biology, is becoming the most important trend to save biological diversity and to expand plant resources (Khalaj $\boldsymbol{e t}$ al., 2013; Uddin, 2014). The physiologically active substances demonstrate allelopathic properties; their chemical nature is very diverse and unstable even within one plant. Allelopathic relationships are very complex because the direct and indirect effects are closely intertwined. Chemical regulation in a plant grouping exists due to the fact that every plant creates a certain allelopathic sphere around it, that is, accumulates collines. The higher the concentration of these collines, the worse the components of the coenosis will grow. Gpiazdowska and Bogatek (2005) presented five levels of plant organization where the effect of allelopathically active substances is manifested: molecular, structural, biochemical, physiological and ecological. In this article, the levels are highlighted in connection with the allelopathically induced symptoms and mechanisms.

Allelopathic relationships are one of the most complex because direct and indirect effects are closely connected (Jafariehyazdi and Javidfar, 2011). Therefore, the central issue of allelopathy is the study of the presence, concentration and chemical composition of collines at all stages of plant development, their physiological activity and the role in agrophytocoenosis. Therefore, the composition of stable high-productive agrophytocoenoses in regard to allelopathic effect is an urgent task which needs a solution (Haig, 2008; Weir et al., 2008; Moosavi et al., 2011). It was shown that most agricultural crops have certain allelopathic effects that can be revealed already at the cell level, specifically, inhibition of enzyme activity, changes in membrane permeability, in exchange of proteins and organic fatty acids; allelopathy affects hormonal status which can activate or suppress antioxidant cell systems. At the level of the whole organism, there are the following effects: stretching of cells, changes in the intensity of respiration, in membrane permeability, in the size of leaf stomata, inhibition of photosynthesis and growth (Rice, 1974; Nekonam et al., 2014; Arowosegbe and Anthony, 2012; Kheibaryan et al., 2012; Weston et al., 2013; Shtyka et al., 2015).

Sorghum (Sorghum bicolor (L.) Moench) is one of the crops possessing a strong allelopathic potential, i.e. capable of forming and allocating physiologically active substances in the medium, and allelopathic tolerance i.e. tolerates the active secretions of other crops. The allelopathic potential of sorghum is demonstrated in numerous publications (Marinov-Serafimov, 2010; Alsaadawi and Dayan, 2009; Shah et al., 2016; Gląb et al., 2017). Storozhyk (2016) found that vegetative and generative parts of sugar sorghum contain biologically active substances such as glycosides, tannins and acids that affect the development of other crops in mixed cropping, specifically height and the number of leaves, the content of sugar, starch, fat, protein, etc. Growing sugar sorghum is advisable due to its high productivity and versatile applications. In Ukraine, at the beginning of the 1990s, the area under sorghum was 20,000-25,000 hectares. Since the beginning of the 2000s, the area under the crop increased to 76,000 hectares. Such a considerable increase in the area under this crop is due to the fact that sorghum is an alternative feedstock for biofuel production and can be grown to harvest grain and green mass (Saballos, 2008). However, it is not advisable to grow sorghum as a single crop for fodder. Previous research showed that sorghum productivity increases in mixed cropping with maize, soybean and sugar beet (Elemo, 2010; Sani $\boldsymbol{e t}$ al., 2011; Kheibaryan et al., 2012).

Mixed planting of two fodder crops is studied and widely used worldwide Mixed cropping of biologically compatible components is a tool to both increase protein content and the yield of fodder (Javanshir et al., 2001; Ngongoni et al., 2008). However, mixed germination of seeds of two crops has ambiguous effects on the development of each crop. For example, when germinating, seeds of sugar sorghum release biologically active substances that 
can affect the growth and development of the other crop in mixed cropping (Storozhyk et al., 2015, 2016).

In view of this, the study of allelopathic substances released by sugar sorghum seeds and their effect on other crops in mixed cropping deserves a special attention. In consideration of the above, the purpose of this research was to study the allelopathic effect of sugar sorghum on the germination of sugar beet seeds.

\section{MATERIALS AND METHODS}

Allelopathic activity of sugar sorghum was studied using a technique by Grodzinsky and Grodzinsky (1973), Scott (2008), Thompson and Hannah (2008) and methodological recommendations developed by the Institute of Bioenergy Crops and Sugar Beet of the National Academy of Agricultural Sciences of Ukraine (Voitovska et al., 2016; Ingle et al., 2018 ). The extraction method was used to study the chemical interaction of plants. In the experiment, fresh seeds of sugar sorghum hybrids 'Medovyi', 'Dovista' and variety 'Sylosne 42' were used. A $50 \mathrm{~g}$ sample of crushed seeds was placed in a glass container, and $250 \mathrm{ml}$ of distilled water was added (1:5). The container was shaken and covered with a lid. The extraction process lasted $24 \mathrm{~h}$ at a temperature of $+20^{\circ} \mathrm{C}$. After that, the extraction solution was poured into a reservoir. Sugar beet seeds of hybrid 'Ukrainskyi MS 97' were put on a filter paper in Petri dish and $7 \mathrm{ml}$ of the extracted solution was added. Petri dishes were put into a thermostat at a temperature of $+25^{\circ} \mathrm{C}$. Germination vigour was determined after 4 days, and germination after 7 days. The experiment was designed in eight replications. The results were compared to the control treatment. Water extractions of various concentrations $(5 \%-50 \%)$ were prepared. Distilled water was used in the control treatment. In the evaluation of sorghum allelopathic effect on sugar beet, we used the most common sorghum hybrid 'Medovyi' with a sugar content of $18 \%$. The extracts of crushed sugar sorghum seeds were filtrated and added to agar culture medium according to the Murashige and Skoog (1962) recommendations with some modifications (George et al., 2008). Clones of sugar beet were planted in vitro on the culture medium. The design of the experiment was as follows: 1) culture medium without sorghum seed extracts (control); 2) culture medium with sorghum seed extracts. The following parameters were used to evaluate the growth rate: the number of buds, the number of leaves and plant height. General condition of the plant was assessed by a five-point scale, where 5 - plants are green and have newly-formed buds; 4 - yellowing of lower leaves, weak bud-formation; 3 - partial change in plant colour and no bud formation; 2 - change in plant colour and partial necrosis; $1-$ necrosis of $95 \%$ of the plant. Analysis of variance, software Microsoft Excel 2010 and AgroStat (Trial version) was used in statistic processing of the obtained data.

\section{RESULTS}

The results of the experiment on the chemical interaction of crops showed that sugar sorghum seeds during germination have both a negative and positive effect on germination and germination vigour of sugar beet. It is important to note that regardless of some cases of stimulating effect, sorghum extracts mostly caused suppression (inhibition) of sugar beet seeds germination. It was found that water extracts from the seeds of 'Medovyi' demonstrated a lesser allelopathic effect compared with other cultivars under study (Fig. 1).

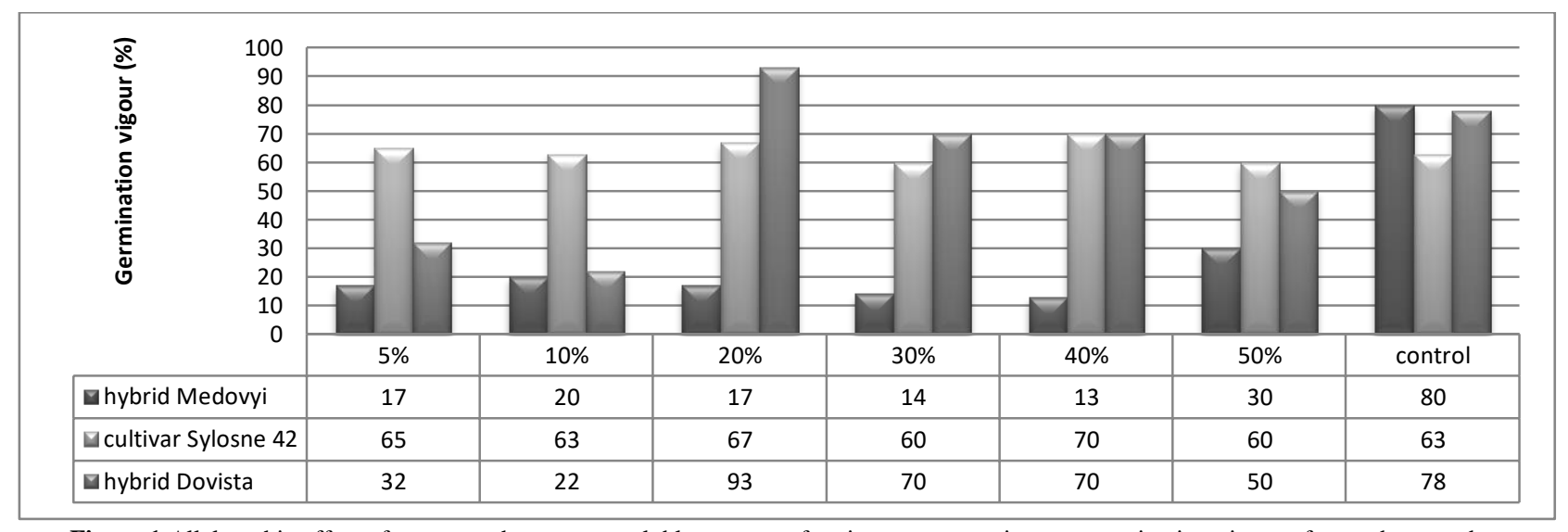

Figure 1 Allelopathic effect of sugar sorghum water-soluble extracts of various concentrations on germination vigour of sugar beet seeds

In the treatments with $40 \%$ water extract from the seeds of 'Medovyi', germination vigour of sugar beet seeds was $13 \%$, which is lower than the control indicators by $83.7 \%$ (Fig. 2). Water extracts of 'Medovyi' with a concentration of $5 \%$ and $10 \%$ demonstrated a considerable phytotoxic effect on sugar beet seeds (Fig. 3).

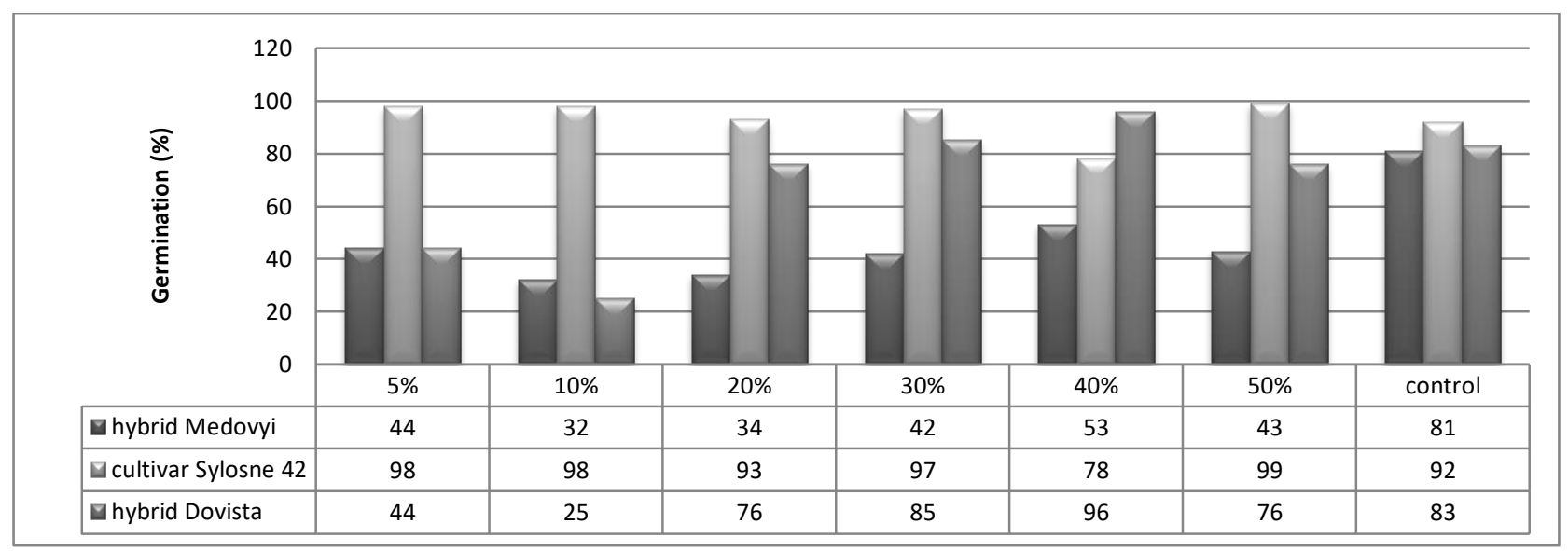

Figure 2 Allelopathic effect of sugar sorghum water-soluble extracts of various concentrations on germination vigour of sugar beet seeds 

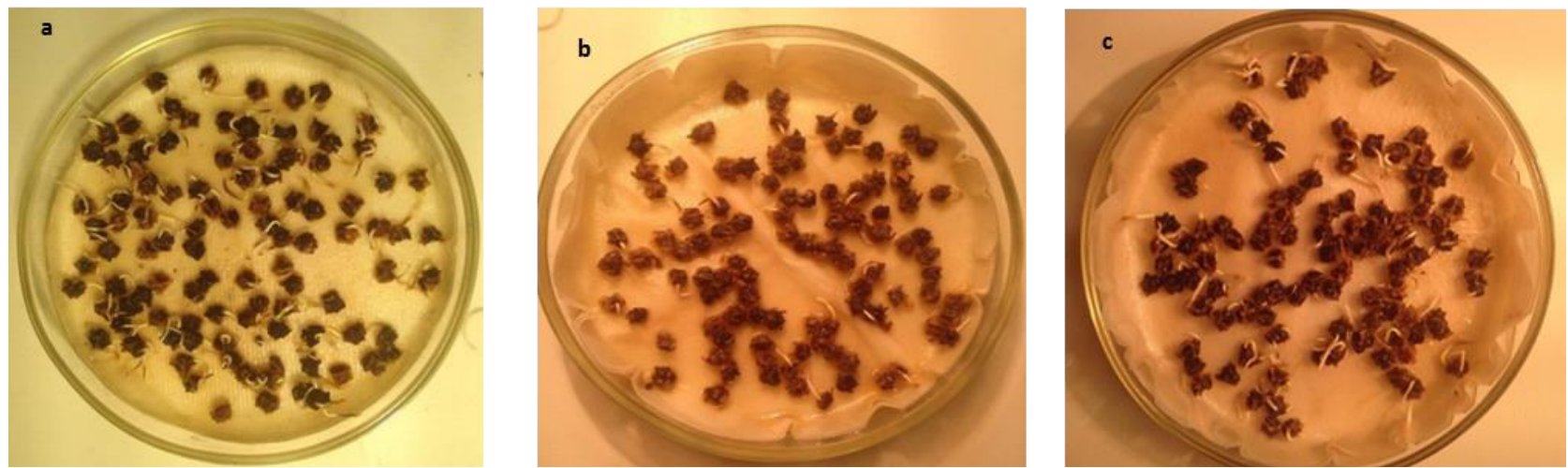

Figure 3 Effect of water extract of sugar sorghum hybrid 'Medovyi' on germination vigour of sugar beet seeds: (A) distilled water - control; (B) 10\%; (C) 40\%.
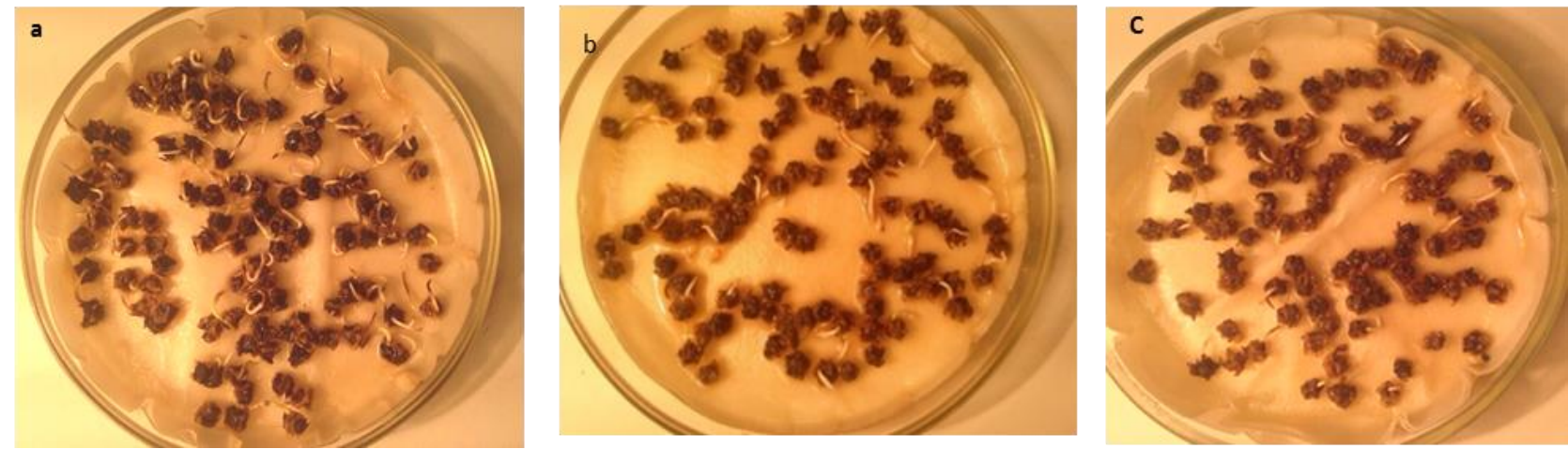

Figure 4 Effect of water extract of sugar sorghum hybrid 'Dovista' on germination vigour of sugar beet seeds: (A) distilled water - control; (B) 5\%; (C) 10\%.
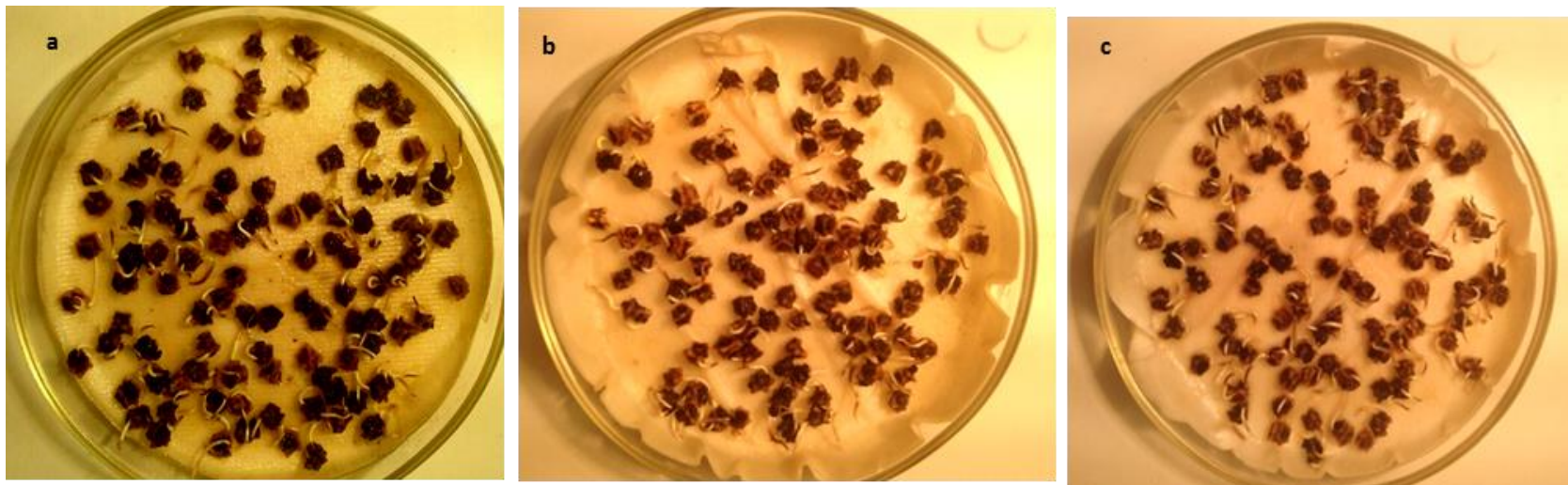

Figure 5 Effect of water extract of sugar sorghum variety 'Sylosne 42' on germination vigour of sugar beet seeds: (A) distilled water - control; (B) 10\%; (C) 40\%.

Water extracts (concentrations 5\% and 10\%) of 'Dovista' caused a serious decrease in germination vigour of sugar beet seeds as compared to the control by $58.9 \%$ and $71.8 \%$, respectively (Fig. 4 ).

Allelopathically active substances from water extracts of 'Sylosne 42' appeared to be relatively tolerant to sugar beet seeds, with $63-65 \%$ germination vigour, i.e. equal to control treatment (Fig. 5).

Accordingly, water extracts from sugar sorghum of various cultivars have both a phytotoxic and stimulation effect on germination and germination vigour of sugar beet seeds. A low stimulation effect (2-5\% compared to control) was recorded in the treatments with $10 \%$ solution of 'Sylosne 42 ' and manifested in more intensive seed germination.

To study the allelopathic effect of extracts from sugar sorghum seeds in vitro, biometric indicators of plants were measured on the $7^{\text {th }}, 14^{\text {th }}$ and $21^{\text {st }}$ day after planting. The results of the experiment showed that on the $7^{\text {th }}$ day, the number of newly formed buds in the treatments was smaller by $0.26 \pm 0.04$, as compared with the control. The number of leaves and a plant height also decreased $(3.78 \pm 0.04$ and $1.6 \pm 0.04 \mathrm{~cm}$, respectively). The general condition of the plants was scored 4 . This proves that on the $7^{\text {th }}$ day, allelopathically active substances have no effect on the plant (Table1).

Table1 Biometric indicators of sugar beet clones in vitro $(\mathrm{n}=8)$ as affected by water extracts from sugar sorghum seeds (hybrid 'Medovyi')

\begin{tabular}{|c|c|c|c|c|}
\hline Treatment & Number of buds & Number of leaves & $\begin{array}{l}\text { Plant height } \\
(\mathrm{cm})\end{array}$ & $\begin{array}{l}\text { The general condition of plants } \\
\text { (score) }\end{array}$ \\
\hline \multicolumn{5}{|l|}{$7^{\text {th }}$ day } \\
\hline Without extracts - control & $1.94 \pm 0.03$ & $4.95 \pm 0.02$ & $1.9 \pm 0.03$ & 5 \\
\hline $\begin{array}{l}\text { Culture medium } \\
\text { with seed extract } \\
14^{\text {th }} \text { day }\end{array}$ & $1.68 \pm 0.05$ & $3.78 \pm 0.04$ & $1.6 \pm 0.04$ & 4 \\
\hline Without extracts - control & $2.73 \pm 0.04$ & $6.12 \pm 0.03$ & $3.5 \pm 0.04$ & 5 \\
\hline $\begin{array}{l}\text { Culture medium } \\
\text { with seed extract }\end{array}$ & $1.34 \pm 0.04$ & $3.35 \pm 0.04$ & $1.6 \pm 0.03$ & 3 \\
\hline \multicolumn{5}{|l|}{$21^{\text {st }}$ day } \\
\hline Without extracts - control & $3.86 \pm 0.02$ & $8.04 \pm 0.02$ & $5.0 \pm 0.04$ & 5 \\
\hline $\begin{array}{l}\text { Culture medium } \\
\text { with seed extract }\end{array}$ & $1.21 \pm 0.03$ & $3.67 \pm 0.05$ & $1.6 \pm 0.02$ & 1 \\
\hline
\end{tabular}


On the $14^{\text {th }}$ day after planting, a decrease in the number of newly formed buds $(1.34 \pm 0.04)$ was recorded in the treatments where culture medium contained sorghum seed extract. Similar changes were observed in regard to the number of leaves and plant height. To illustrate, in the control treatment these indicators were $6.12 \pm 0.03$ and $3.5 \pm 0.04 \mathrm{~cm}$, respectively but on the culture media containing sorghum seed extract $3.35 \pm 0.04$ and $1.6 \pm 0.03 \mathrm{~cm}$, respectively. In the treatment with seed extracts, the score of the general condition of plants decreased from 5 to 3 . On the $21^{\text {st }}$ day in the contro treatment (culture medium without sorghum extracts), the number of newly formed buds was $3.86 \pm 0.02$ and the number of leaves $8.04 \pm 0.02$, respectively, plant height was $5.0 \pm 0.04 \mathrm{~cm}$ and general condition 5 (Fig. 6). On culture media with sorghum seed extracts, these biometric indicators were $11.21 \pm 0.03,3.67 \pm 0.05,1.6 \pm 0.02 \mathrm{~cm}$ and 1 point, respectively.
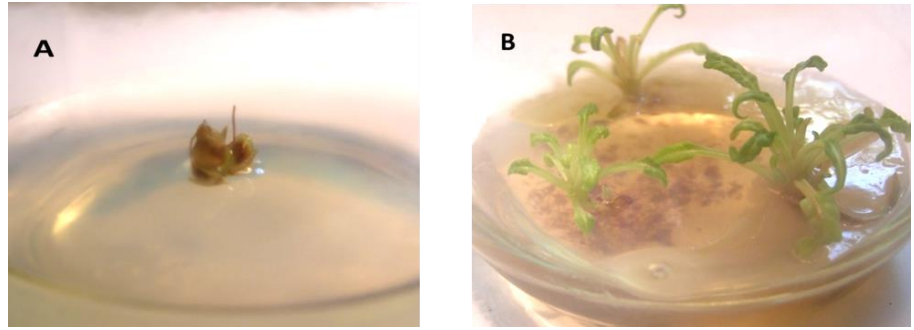

Figure 6 Sugar beet planted on culture medium without sugar sorghum seed extract on the $7^{\text {th }}$ day (A) and on the $21^{\text {st }}$ day (B)

On the $21^{\text {st }}$ day of the experiment, the effect of allelopathically active substances resulted in gradual suppression of sugar beet plants, and eventually in their dying off (Fig. 7).
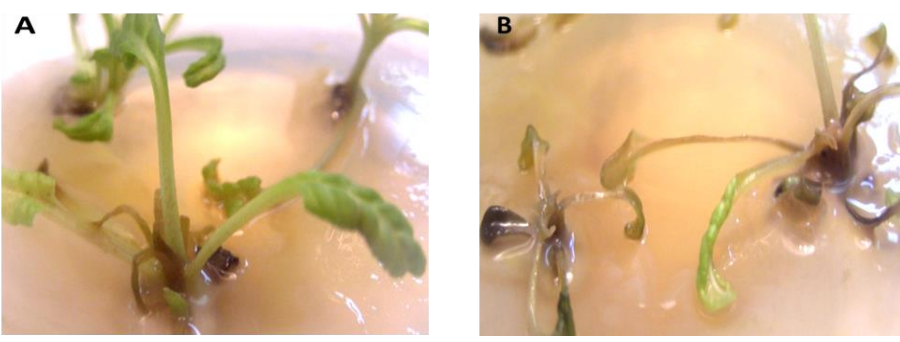

Figure 7 Sugar beets planted on culture medium with seed extract of sugar sorghum in vitro: $14^{\text {th }}$ day, gradual suppression (A) and $21^{\text {st }}$ day, death (B)

The above-described effect has to be taken into account when planning mixed cropping or using sugar sorghum as green manure. These issues have not been studied enough yet and require further investigation.

\section{DISCUSSION}

The research of Ukrainian (Grodzinsky and Grodzinsky, 1973; Đikic, 2005 a; b; Koval and Yeshchenko, 2011; Storozhyk, 2015) and foreign scientists (Chou, 2006; Seigler, 2006; Fujii, Hiradate, 2007; Bhadoria, 2011; Baličević, 2015; Alsaadawi et al., 2015; Novak et al, 2018) proved a possible allelopathic or chemical interaction of plants through the release of biologically active substances. For example, in the laboratory experiment, water extracts from harvest residues of barley, winter wheat, pea, maize, sunflower and spring rapeseed demonstrated a positive effect on germination vigour of spring rapeseed, speeding up its initial development. On the contrary, water extracts from sugar beet tops were toxic to plants and inhibited growth. The laboratory germination of flax seeds increased as the result of the effect of water extracts of soybean, maize, and pea harvest residues, while water extracts of sugar beet considerably suppressed germination and inhibited the initial growth of flax sprouts.

Allelopathic properties of the plant material vary by the kind of plant tissue, the age of plant and cultivar. Allelopathic activity changes in the process of ontogenesis and under the effect of external factors (Marchi et al., 2008; Weston et al., 2013). For example, green leaves contain many physiologically active substances; their number increases as the age of a plant increases, and decreases after plant dying off. Kumar and Gautam (2008), Mohanan and Rajendiran (2013) found that collines are mostly concentrated in leaves and generative organs of plants. Their content in roots is 1.6-9 times lower, and the highest values are observed at the stage of flowering. Literature data prove that seeds also demonstrate the allelopathic effect (Moosavi et al., 2011; Makoi and Ndakidemi, 2012; Alsaadawi et al., 2015). American researchers presented an experimentally proven hypothesis that seeds release some chemical substances in soil solution in a very little amount; being accepted by seeds of other species these substances determine a level of interaction in phytocoenosis. Because of a very small amount of extracted substances, they are regarded as 'information molecules' (Khaliq et al., 2013; Weston $\boldsymbol{e t}$ al., 2013; Yarnia et al., 2009; Al-Tawaha and Odat, 2010.). There are several ways of using allelopathic activity of sorghum for weed control in field conditions. They are not limited to the growing sorghum as a single crop, or in mixed cropping. Allelopathic effect of sorghum mulch or sorghum as cover crop may be used too (Marinov-Serafimov, 2010; Al-Bedairy et al., 2013; Rab et al., 2016; Jabran, 2017).

Koval and Yeshchenko (2011) point out to the contradiction of allelopathic effects in laboratory and field experiment. Despite the fact that the effects obtained in laboratory conditions do not always conform to the results obtained in field, the contradiction can be explained as follows: active substances released in soil undergo fast mineralization and participate in humus formation; phenolic compounds, which are intermediaries in humus substances and available in the soil in a free state, can act allelopathically (Tharayil et al., 2008a,b; Alsaadawi et al., 2015). Thus, their toxic and stimulating effect are equal at the moment of sowing. Ashrafi et al., (2008) and Al-Tawaha and Odat (2010) found that decomposition of maize and sorghum residues increases phenolic compounds in the soil affecting barley germination. Anjum and Bajwa (2010) showed that allelopathically active maize substances affect wheat yield.

In a research carried out earlier it was found that when sugar sorghum was cultivated in mixed cropping with mother roots of sugar beet, a mutual effect on growth and development of both crops was observed. At the beginning of vegetation, when there is enough moisture and nutrients in the soil, each crop is supplied with an equal amount of environmental factors (solar radiation, temperature), and no sign of mutual suppression of the crops is recorded. As the main crop grows, the growth of mother roots of sugar beet slows down. In fact, this situation lasts until the harvesting of the main crop. However, some inhibition of the growth and development of sorghum was observed as well. The results of the laboratory experiments showed that water extracts from sugar sorghum seeds have both phytotoxic and a stimulating effect on germination and germination vigour of sugar beet seeds. The degree of the phytotoxic effect depends on the concentration of extracts.

In the treatment with $40 \%$ water extract from seeds of 'Medovyi', germination vigour of sugar beet seeds was $13 \%$, i.e. $83.7 \%$ lower compared to control; meanwhile, $70 \%$ water extract of 'Sylosne 42 ' increased the value of by $7 \%$ the control. The extract of 'Dovista' of the same concentration resulted in $70 \%$ germination vigour. That is, $40 \%$ extract of 'Sylosne 42 ' had a weak stimulating effect on sugar beet germination compared with 'Medovyi', which had a significant phytotoxic effect on seed germination.

The inhibiting effect of the extracts on germination in most cases increases along with the increase in the extract concentration (Yarnia, 2009). Nganthoi (2014), Msafiri et al., (2013) and others found out that a high concentration of water extract of Parthenium hysterophorus leaves also had a strong inhibiting effect on the germination of some cultivated and wild plant varieties. It was shown that the allelopathic effect of all sunflower extracts increases as their concentration increases (Ashrafi et al., 2008). Devi and Dutta (2012) recorded a strong positive correlation between the increase in the concentrations of harvest residues extract and the decrease of a seedling height of genus Brassica.

The technologies of plant cultivation in vitro are used to study potential allelopathic activity. From the methodological point of view, it remains unclear whether phytotoxicity found in vitro turns into allelopathic effect under more complicated ecological conditions (Singh et al., 2009; Qasem, 2010; Rad et al., 2014; Jandová et al., 2015).

Analysis of the research results showed that allelopathically active substances from sorghum seed extracts revealed no effect on the clones and plants of sugar beet on the $7^{\text {th }}$ day after planting; a decrease in the number of formed buds, leaves and plant height was observed on the $14^{\text {th }}$ day and gradual suppression and eventually dying off on the $21^{\text {st }}$ day.

\section{CONCLUSIONS}

Water extracts from sugar sorghum seeds of different cultivars and of various concentrations (from 5\% to 50\%) have both a toxic and stimulating effect on germination and germination vigour of sugar beet seeds. In the treatment with $40 \%$ water extract from the seeds of sugar sorghum hybrid 'Medovyi', germination vigour of sugar beet seeds was $13 \%$, which was by $83.7 \%$ lower compared the control treatment. A phototoxic effect in regard to sugar beet seeds is typical for $10 \%$ water extract of hybrid 'Dovista' decreasing germination vigour by $71.8 \%$ and seed germination by $69.9 \%$ as compared to the control.

Water extracts of sorghum variety 'Sylosne 42' appeared relatively tolerant to sugar beet seed germination. In this treatment, the value of germination (63$65 \%$ ) conformed to the results of the control treatment.

Allelopathically active substances from sorghum seed extracts revealed no effect on the clones and plants of sugar beet on the $7^{\text {th }}$ day after planting; a decrease in the number of formed buds, leaves and plant height was observed on the $14^{\text {th }}$ day and gradual suppression and eventually dying off on the $21^{\text {st }}$ day. 
Investigation of the possibilities of using water extracts from sugar sorghum as natural inhibitors of weed growth will be the topic of our further research.

When planning agrophytocoenoses, the effects of plant extracts should be taken into account. The random selection of physiologically incompatible components for mixed cropping may result in a sharp decline in yield and worsen its quality.

\section{REFERENCES}

Al-Bedairy, N. R., Alsaadawi, I. S., \& Shati, R. K. (2013). Combining effect of allelopathic Sorghum bicolor L. (Moench) cultivars with planting densities on companion weeds. Archives of Agronomy and Soil Science, 59(7), 955-961. https://doi.org/10.1080/03650340.2012.697995

Alsaadawi, I. S., \& Dayan, F. E. (2009). Potential and prospect of sorghum allelopathy in agroecosystem. Allelopathy Journal, 24(2), 255-270.

Alsaadawi, I. S., Alkhateeb, T. A., Hadwan, H. A., \& Lahmood, N. R. (2015) A chemical basis for differential allelopathic potential of root exudates of Sorghum bicolor L. (Moench) cultivars on companion weeds. Journal of Allelochemicals Interactions, 1(1), 49-55.

Alsaadawi, I. S., Alkhateeb, T. A., Hadwan, H. A., \& Lahmood, N. R. (2015) A chemical basis for differential allelopathic potential of root exudates of Sorghum bicolor L. (Moench) cultivars on companion weeds. Journal of Allelochemicals Interactions, 1(1), 49-55.

Al-Tawaha, A. R. M., \& Odat, N. (2010). Use of sorghum and maize allelopathic properties to inhibit germination and growth of wild barley (Hordeum spontaneum). Notulae Botanicae Horti Agrobotanici Cluj-Napoca, 38(3), 124-127. http://dx.doi.org/10.15835/nbha3834782

Anjum, T., \& Bajwa, R. (2010). Sunflower phytochemicals adversely affect wheat yield. Natural Product Research, 24(9), 825-837. http://dx.doi.org/10.1080/14786410902904426

Arowosegbe, S., \& Afolayan, A. J. (2012). Assessment of allelopathic properties of Aloe ferox Mill. on turnip, beetroot and carrot. Biological Research, 45(4), 363-368. $\quad$ http://dx.doi.org/10.4067/S071697602012000400006

Ashrafi, Z. Y., Sadeghi, S., Mashhadi, H. R., \& Hassan, M. A. (2008) Allelopathic effects of sunflower (Helianthus annuus) on germination and growth of wild barley (Hordeum spontaneum). Journal of Agricultural Technology, 4(1), 219-229.

Baličević, R., Ravlić, M., \& Živković, T. (2015). Allelopathic effect of invasive species giant goldenrod (Solidago gigantean Ait.) on crops and weeds. Herbologia, 15(1), 19-29. http://dx.doi.org/10.5644/Herb.15.1.03

Bhadoria, P. B. S. (2011). Allelopathy: A natural way towards weed management. American Journal of Experimental Agriculture, 1(1), 7-20. http://dx.doi.org/10.9734/AJEA/2011/002

Chou, C. H. (2006). Introduction to allelopathy. In M. Reigosa, N. Pedrol, \& L. González (Eds.), Allelopathy: a physiological process with ecological implications (pp. 1-9). Dordrecht, Netherlands: Springer. https://doi.org/10.1007/1-4020-4280-9

Devi, N. Y., Dutta, B. K., Sagolshemcha, R., \& Singh, N. I. (2014) Allelopathic effect of Parthenium hysterophorus L. on growth and productivity of Zea mays L. and its phytochemical screening. International Journal of Current Microbiology and Applied Sciences, 3(7), 837-846.

Devi, O. I., \& Dutta, B. K. (2012). Allelopathic effect of the aqueous extract of Parthenium hysterophorus and Chromolaena odorata on the seed germination and seedling vigour of Zea mays L. in vitro. Applied Journal of Plant Science, 5(4), 110-113. http://dx.doi.org/10.5829/idosi.ajps.2012.5.4.321

Đikic, M. (2005a). Allelopathic effect of aromatic and medicinal plants on the seed germination of Galinsoga parviflora, Echinochloa crus-galli and Galium molugo. Herbologia, 6(3), 51-57.

Đikis, M. (2005b). Allelopathic effect of cogermination of aromatic and medicinal plants and weed seeds. Herbologia, 6(1), 15-24.

Elemo, K. A. (2010). Productivity of maize/sorghum intercrop as influenced by component crop density and arrangement. Journal of Agricultural Science and Environment, 10(2), 25-35.

Fujii, Y., \& Hiradate, S. (Eds.). (2007). Allelopathy: new concepts and methodology (pp. 3-59). Enfield, NH, USA: Science Publishers.

George, E. F., Hall, M. A., \& de Klerk, G.-J. (2008). The Components of Plant Tissue Culture Media I: Macro- and Micro-Nutrients. In E. F. George, M. A. Hall, \& G.-J. De Klerk (Eds.), Plant Propagation by Tissue Culture (pp. 65 113). (3rd ed). Dordrecht: Springer.

Głąb, L., Sowiński, J., Bough, R., \& Dayan, F. E. (2017). Allelopathic potential of sorghum (Sorghum bicolor (L.) Moench) in weed control: a comprehensive review. Advances in Agronomy, 145, 43-95. https://doi.org/10.1016/bs.agron.2017.05.001

Gniazdowska, A., \& Bogatek, R. (2005). Allelopathic interactions between plants. Multi site action of allelochemicals. Acta Physiologiae Plantarum, 27(3), 395-407. http://dx.doi.org/10.1007/s11738-005-0017-3

Grodzinsky, A. M., \& Grodzinsky, D. M. (1973). A brief reference book on the physiology of plants (pp. 12-153). Kyiv: Naukova Dumka (in Russian)
Haig, T. (2008). Allelochemicals in Plants. In R. S. Zeng, A. U. Mallik, \& S. M. Luo (Eds.), Allelopathy in sustainable agriculture and forestry (pp. 63-104). New York, USA: Springer. https://doi.org/10.1007/978-0-387-77337-7_4

Ingle, K. P., Deshmukh, A. G., Padole, D. A., Dudhare, M. S., Moharil, M. P. \& Khelurkar, V. C. (2017). Phytochemicals: Extraction methods, identification and detection of bioactive compounds from plant extracts. Journal of Pharmacognosy and Phytochemistry, 6(1), 32-36.

Jabran, K. (2017). Sorghum allelopathy for weed control. In Manipulation of allelopathic crops for weed control (pp. 65-75). Cham: Springer. https://doi.org/10.1007/978-3-319-53186-1_8

Jafariehyazdi, E., \& Javidfar, F. (2011). Comparison of allelopathic effects of some brassica species in two growth stages on germination and growth of sunflower. Plant Soil and Environment, 57(2), 52-56. https://doi.org/10.17221/139/2010-PSE

Jandová, K., Dostál, P., \& Cajthaml, T. (2015). Searching for Heracleum mantegazzianum allelopathy in vitro and in a garden experiment. Biological Invasions, 17(4), 987-1003. https://doi.org/10.1007/s10530-014-0771-5

Javanshir, A., Dabbagh Mohammadi Nasab, A., Hamidi, A. \& Gholipoor, M (2001). Ecology of Intercropping. Mashhad: Jihad Mashhad University Press (in Persian with English abstract)

Khalaj, M. A., Amiri, M., \& Azimi, M. H. (2013). Allelopathy; hysiological and sustainable agriculture impact aspects. International Journal of Agronomy and Plant Production, 4(5), 950-962.

Khaliq, A., Matloob, A., Mahmood, S., \& Wahid, A. (2013). Seed pretreatments help improve maize performance under sorghum allelopathic stress. Journal of Crop Improvement, 27(5), 586-605. https://doi.org/10.1080/15427528.2013.812051

Kheibaryan, R. A., Alipoor, Z., Laei, Gh., \& Fanoodi, F. (2012). Studying the function of fodder in the mixed farming of millet, Sorghum, sunflower and fodder corn in Damghan. Annals of Biological Research, 3(9), 4337-4342.

Koval, S. P., \& Yeshchenko, V. O. (2011). Allelopathic effect of water extracts from above-ground plant residues of various forecrops on germination, initial growth and height of oil-bearing flax. Collection of scientific works of Uman State Agrarian University. Part 1. Agronomy, 69, 101-106 (in Ukrainian)

Kumar, G., \& Gautam, N. (2008). Allelotoxicity of Parthenium leaf extract on cytomorphological behavior of sunflowers (Helianthus annuus). Journal of Environmental Biology, 29(2), 243-247.

Makoi, J. H. J. R., \& Ndakidemi, P. A. (2012). Allelopathy as protectant, defence and growth stimulants in legume cereal mixed culture systems. New Zealand Journal of Crop and Horticultural Sciences, 40(3), 161-186. https://doi.org/10.1080/01140671.2011.630737

Marchi, G. I., Marchi, E. C. S., Wang, G., \& Mcgiffen, M. (2008). Effect of age of a sorghum-sudangrass hybrid on its allelopathic action. Planta Daninha, 26(4), 707-714. http://dx.doi.org/10.1590/S0100-83582008000400001

Marinov-Serafimov, P. (2010). Determination of allelopathic effect of some invasive weed species on germination and initial development of grain legume crops. Pesticides and Phytomedicine, 25(3), 251-259. http://dx.doi.org/10.2298/PIF1003251M

Mohanan, H., \& Rajendiran, K. (2013). Allelopathy and cytotoxicity of aqueous extracts of Parthenium hysterophorus L. on Oryza sativa L. Var.Asd16. International Journal of Food, Agriculture and Veterinary Sciences, 3(3), 55-61.

Moosavi, A., Afshari, R. T., Asadi, A., \& Gharineh, M. H. (2011). Allelopathic Effects of Aqueous Extract of Leaf Stem and Root of Sorghum bicolor on Seed Germination and Seedling Growth of Vigna radiata L. Notulae Scientia Biologicae, 3(2), 114-118. http://dx.doi.org/10.15835/nsb325862

Msafiri, C. J., Tarimo, M. T., \& Ndakidemi, P. A. (2013). Allelopathic effects of Parthenium hysterophorus on seed germination, seedling growth, fresh and dry mass production of Alysicurpus glumaceae and Chloris gayana. American Journal of Research Communication, 1(11), 190-205.

Murashige, T., \& Skoog, F. (1962). A revised medium for rapid growth and bioassay with tobacco tissue culture. Physiologia Plantarum, 15(3), 473-497. https://doi.org/10.1111/j.1399-3054.1962.tb08052.x

Nekonam, M. S., Razmjoo, J., Kraimmojeni, H., Sharif, B., Amini, H., \& Bahrami, F. (2014). Assessment of some medicinal plants for their allelopathic potential against redroot pigweed (Amaranthus retroflexus). Journal of Plant Protection Research, 54(1), 90-95.

Ngongoni, N. T., Mwale, M., Mapiye, C., Moyo, M. T., Hamudikuwanda, H., \& Titterton, M. (2008). Research note: Inclusion of lablab in maize and sorghum silages improves sheep performance. Tropical Grasslands, 42, 188192

Novak, N., Novak, M., Barić, K., Šćepanović, M., \& Ivić, D. (2018). Allelopathic potential of segetal and ruderal invasive alien plants. Journal of Central European $\quad$ Agriculture, 19(2), 408-422. http://dx.doi.org/10.5513/JCEA01/19.2.2116

Qasem, J. R. (2010). Differences in the allelopathy results from field observations to laboratory and glasshouse experiments. Allelopathy Journal, 26(1), 45-58.

Rab, A., Khalil, S. K., Asim, M., Mehmood, N., Fayyaz, H., Khan, I., ... Nawaz, H. (2016). Response of sorghum (Sorghum bicolor L.) extract type, 
concentration and application time to weeds weight, grain and biomass yield of wheat. Pure and Applied Biology, 5(4), 847-855. http://dx.doi.org/10.19045/bspab.2016.50106

Rad, J. S., Rad, M. S., \& da Silva, J. A. T. (2014). Evaluation of allelopathic effects of methanolic extracts from Salicornia herbacea seed and leaves on germination and seedling growth in vitro of two medicinal plants and two weeds. Environmental and Experimental Biology, 12, 83-87.

Rice, E. L. (1974). Allelopathy. New York: Academic Press.

Saballos, A. (2008). Development and utilization of sorghum as a bioenergy crop. In W. Vermerris (Ed.), Genetic Improvement of Bioenergy Crops (pp. 211-248). New York, USA: Springer. http://dx.doi.org/10.1007/978-0-38770805-8_8

Sani, B. M., Danmowa, N. M., Sani, Y. A., \& Jaliya, M. M. (2011). Growth, Yield and Water Use Efficiency of Maize-Sorghum Intercrop at Samaru, Northern Guinea Savannah, Nigerian. Nigerian Journal of Basic and Applied Science, 19(2), 253-259

Scott, P. (2008). Physiology and behaviour of plants. Chichester, UK: John

Wiley \& Sons Ltd.

Seigler, D. S. (2006). Basic pathways for the origin of allelopathic compounds. In M. Reigosa, N. Pedrol, \& L. González (Eds.), Allelopathy: a physiological process with ecological implications (pp. 11-61). Dordrecht, Netherlands: Springer. https://doi.org/10.1007/1-4020-4280-9_2

Shah, S. H., Khan, E. A., Shah, H., Ahmad, N., Khan, J., \& Sadozai, G. U. (2016). Allelopathic sorghum water extract helps to improve yield of sunflower (Helianthus annuus L.). Pakistan Journal of Botany, 48(3), 1197-1202.

Shtyka, O., Bilyk, T., \& Andrushchenko, O. (2015). Allelopathical activity assessment as the important stage of phytoremediation technology development. Proceedings of the National Aviation University, 2, 79-87. http://dx.doi.org/10.18372/2306-1472.63.8866

Singh, N. B., Pandey, B. N., \& Singh, A. (2009). Allelopathic effects of Cyperus rotundus extract in vitro and ex vitro on banana. Acta Physiologiae Plantarum, 31(3), 633-638. https://doi.org/10.1007/s11738-009-0274-7

Storozhyk, L. I., Voytovskaya, V. I., \& Nedyak, T. N. (2015). Inhibition of phenolic compounds of sweet sorghum in vitro. Sci-Article.ru, 21, 17-26. http://sci-article.ru/number/05 2015.pdf (in Russian)

Storozhyk, L. I., Voytovskaya, V. I., \& Nedyak, T. N. (2016). Influence of allelopatically active substances obtained from various sorghum organs on sugar beet. Sci-Article.ru, 30, 180-190. http://sciarticle.ru/number/04_2016.pdf (in Russian)

Tharayil, N., Bhowmik, P. C., \& Xing, B. (2008a). Bioavailability of allelochemicals as affected by companion compounds in soil matrices. Journal of Agricultural and Food Chemisry, 56(10), 3706-3713. http://dx.doi.org/10.1021/jf073310a

Tharayil, N., Bhowmik, P. C., Alpert, P., Walker, E., Amarasiriwardena, D., Xing, B. (2008b). Dual purpose secondary compounds: Phytotoxins of Centaurea diffusa also facilitates nutrient uptake. New Phytologist, 181(2), 424-434. http://dx.doi.org/10.1111/j.1469-8137.2008.02647.x

Thompson, P. B., \& Hannah, W. (2008). Food and agricultural biotechnology: a summary and analysis of ethical concerns. Advances in Biochemical Engineering/Biotechnology,

111 $229-264$ http://dx.doi.org/10.1007/10_2008_100

Uddin, Md. N. (2014). Ecological implications of allelopathic interferences with reference to Phragmites australis ( $\mathrm{PhD}$ thesis). Victoria University, Melbourne, Australia.

Voitovska, V. I., Storozhyk, L. I., Nediak, T. M., \& Prysiazhniuk, O. I. (2016) Determination of the resistance of plants to the action of the allelolpathic substances of sweet sorghum. Methodical recommendation. Kyiv: Institute of Bioenergy Crops and Sugar Beet of National Academy Agricultural Sciences of Ukraine (in Ukrainian)

Weir, T. L., \& Vivanco, J. M. (2008). Allelopathy: Full Circle from Phytotoxicity to Mechanisms of Resistance. In R. S. Zeng, A. U. Mallik, \& S. M. Luo (Eds.), Allelopathy in sustainable agriculture and forestry (pp. 105115). New York, USA: Springer. https://doi.org/10.1007/978-0-387-77337-7_5 Weston, L. A., Alsaadawi, I. S., \& Baerson, S. R. (2013). Sorghum allelopathy - from ecosystem to molecule. Journal of Chemical Ecology, 39(2), 142-153. https://doi.org/10.1007/s10886-013-0245-8

Yarnia, M., Khorshidi Benam, M. B., \& Farajzadeh Memari Tabrizi, E. (2009) Allelopathic effects of sorghum extracts on Amaranthus retroflexus seed germination and growth. Journal of Food, Agriculture and Environment, 7(3-4), 770-774. 